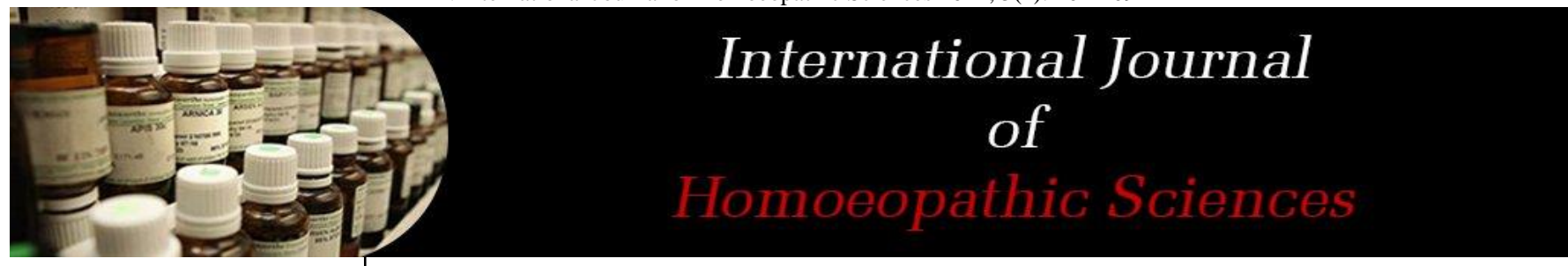

E-ISSN: $2616-4493$ P-ISSN: 2616-4485 www.homoeopathicjournal.com IJHS 2021; 5(1): 201-209 Received: 09-11-2020 Accepted: 19-12-2020

Dr. Krishneswari RS Assistant Professor, Department of Practice of Medicine, National Homoeopathy Research Institute in Mental Health, Kottayam, Kerala, India

Dr. KC Muraleedharan Professor and HOD, Department of Practice of Medicine, Officer in Charge, National Homoeopathy Research Institute in Menta Health, Kottayam, Kerala, India
Corresponding Author: Dr. Krishneswari RS Assistant Professor, Department of Practice of Medicine, National Homoeopathy Research Institute in Mental Health, Kottayam, Kerala, India

\section{A systematic review on the pathogenesis of death due to COVID-19}

\author{
Dr. Krishneswari RS and Dr. KC Muraleedharan
}

DOI: https://doi.org/10.33545/26164485.2021.v5.i1d.314

\begin{abstract}
Background: A pandemic COVID-19 affected the whole world since December 2019. By this review an attempt is made to find the pathogenesis behind the death of patients from the available literature on post-mortem findings. A trial is made to find out suitable Homoeopathic medicines based on pathological findings.

Methods: Eight research articles having the post-mortem findings of deceased due to COVID-19 are selected and a review is done with statistical analysis to find the prevalence of pathogenesis.

Results: Ground glass opacity is the common finding in chest imaging, virus like particles is seen in the lung parenchyma and the prevalent pathogenesis is found to be Diffuse Alveolar Damage (81.93\%) of the lung tissue. Arsenicum album is found to be the leading remedy.

Conclusion: The prevalent pathological finding is found to be Diffuse Alveolar Damage in the lungs which is a feature consistent with fatal viral infection leading to Acute Respiratory Distress Syndrome.
\end{abstract}

Keywords: COVID-19, Post-mortem, diffuse alveolar damage, acute respiratory distress syndrome

\section{Introduction}

The world population is witnessing increased number of pneumonia like infections and numerous deaths all over the planet since the last month of 2019 caused by a novel strain of Corona virus. The disease is named Corona Virus Disease 2019 (COVID-19) and the virus is named Severe Acute Respiratory Syndrome Corona Virus-2 (SARS-CoV-2)

The three possible characteristics of dying process in COVID-19 are thought to be:

a) Predominant terminal organ failure such as terminal respiratory failure, septic shock, multiple organ failure, cardiogenic shock and other.

b) Proportionality of care in the dying process such as withholding life support, withdrawing life support, full care with or without cardiopulmonary resuscitation.

c) Involvement of COVID-19 in the dying process like death attributed only to COVID-19, death primarily due to old age, frailty or advanced diseases and death due to COVID-19 in individual whose life expectancy is limited ${ }^{[1]}$.

A study conducted on the predictors of mortality in COVID -19 in Wuhan, China showed that patients of age above 65 years and pre -existing concurrent cardiovascular or cerebrovascular diseases with increased cardiac troponin $\mathrm{I}$ and $\mathrm{CD}^{3+} \mathrm{CD}^{8+} \mathrm{T}$ cells are having high mortality among overall population ${ }^{[2]}$.

Although few studies regarding the post-mortem findings in the deceased are published, this is a trial to record the pathogenesis of death due to COVID-19 from the available research papers on post-mortem findings in SARS $-\mathrm{CoV}-2$ positive patients. A trial was made to repertories the pathology from the available rubrics and to found out suitable Homoeopathic medicines.

\section{Methods}

A literature search was conducted using the words "death in COVID-19", "autopsy findings", "post-mortem findings in COVID-19" from various databases of PubMed, Jama network, Springer nature and the Lancet. Google search engine was used to collect all relevant research articles and reports published till $3^{\text {rd }}$ June 2020. Eight research articles were selected which includes the histopathological as well as macroscopical appearance of the tissues in patients who died of COVID-19. Preferred Reporting Items for Systematic reviews and MetaAnalyses extension for Scoping Reviews (PRISMA-ScR) checklist is used for the review of these selected articles. 
The available data obtained from all the eight selected research articles were extracted and tabulated. A general conclusion was made on the available data by finding the prevalence of presenting pathological changes. Radar opus 2.2.16 software was used for repertorisation of available pathological rubrics.

\section{Result}

Title and Objectives of the articles

The title, objectives, authors and publishers of the articles are summarised as follows:

Table 1: Title and objectives of the selected articles

\begin{tabular}{|c|c|c|c|}
\hline \begin{tabular}{|c|} 
S. \\
No.
\end{tabular} & Title & Authors and Publishers & Objective \\
\hline 1 & $\begin{array}{l}\text { Pathological study of the } 2019 \\
\text { novel coronavirus disease } \\
\text { (COVID-19) through post- } \\
\text { mortem core biopsies. }\end{array}$ & $\begin{array}{c}\text { Sufang Tian; Yong Xiong; Huan Liu et al. Modern } \\
\text { Pathology, https://doi.org/10.1038/s41379-020-0536-x, } \\
\text { Published online on 14 April 2020. }\end{array}$ & $\begin{array}{c}\text { To gain knowledge about the pathology } \\
\text { that may contribute to disease progression } \\
\text { and fatality through post-mortem needle } \\
\text { core biopsies of lung, liver and heart in } \\
\text { four patients who died of COVID-19 } \\
\text { pneumonia. }\end{array}$ \\
\hline 2 & $\begin{array}{l}\text { COVID-19 Autopsies, } \\
\text { Oklahoma, USA }\end{array}$ & \begin{tabular}{|c} 
Lisa M. Barton, MD, PhD; Eric J. Duval, DO; Edana \\
Stroberg, DO et al. Am J Clin Pathol, June 2020; 153: 725- \\
733.
\end{tabular} & $\begin{array}{l}\text { To report the methods and findings of two } \\
\text { complete autopsies of severe acute } \\
\text { respiratory syndrome coronavirus } 2 \\
\text { (SARS-COV-2) positive individuals who } \\
\text { died in Oklahoma (United States) in March } \\
2020 .\end{array}$ \\
\hline 3 & $\begin{array}{l}\text { Post mortem Examination of } \\
\text { Patients with COVID-19. }\end{array}$ & $\begin{array}{c}\text { Tina Schaller, MD; Klaus Hirschbühl, MD; Katrin } \\
\text { Burkhardt, MD et al. American Medical Association, } \\
\text { https://jamanetwork.com } \\
\text { Published online May } 21,2020\end{array}$ & $\begin{array}{c}\text { To describe postmortem examinations in a } \\
\text { case series of patients with COVID-19 to } \\
\text { get data on cause of death }\end{array}$ \\
\hline 4 & $\begin{array}{c}\text { Pulmonary and cardiac } \\
\text { pathology in African American } \\
\text { patients with COVID-19: an } \\
\text { autopsy series from New } \\
\text { Orleans. } \\
\end{array}$ & $\begin{array}{c}\text { Sharon E Fox; Aibek Akmatbekov; Jack L Harbert et al. } \\
\text { Lancet Respir Med2020, https://doi.org/10.1016/S2213- } \\
\text { 2600(20) 30243-5, } \\
\text { Published Online May 27, } 2020 .\end{array}$ & $\begin{array}{c}\text { To report the relevant cardiopulmonary } \\
\text { findings of } 10 \text { Africo American decedents } \\
\text { whose cause of death is attributed to } \\
\text { COVID-19 }\end{array}$ \\
\hline 5 & $\begin{array}{l}\text { Pulmonary post-mortem } \\
\text { findings in a large series of } \\
\text { COVID-19 cases from } \\
\text { Northern Italy. }\end{array}$ & $\begin{array}{c}\text { Luca Carsana, MD; Aurelio Sonzogni, MD; Ahmed Nasr, } \\
\text { MD; et al. https://doi.org/10.1101/2020.04.19.20054262, } \\
\text { Posted April 22, 2020. }\end{array}$ & $\begin{array}{c}\text { To determine the histological patterns in } \\
\text { lung tissue of patients with severe COVID- } \\
19 .\end{array}$ \\
\hline 6 & $\begin{array}{c}\text { Autopsy Findings and Venous } \\
\text { Thromboembolism in Patients } \\
\text { With COVID-19 }\end{array}$ & $\begin{array}{c}\text { Dominic Wichmann, MD; Jan-Peter Sperhake, MD; Marc } \\
\text { Lütgehetmann, MD et al. Annals of Internal Medicine, } 6 \\
\text { May, 2020, } \\
\text { https://doi.org/10.7326/M20-2003. }\end{array}$ & $\begin{array}{l}\text { To validate and compare clinical findings } \\
\text { with data from medical autopsy, virtual } \\
\text { autopsy, and virologic tests. }\end{array}$ \\
\hline 7 & $\begin{array}{c}\text { Pulmonary Vascular } \\
\text { Endothelialitis, Thrombosis, } \\
\text { and Angiogenesis in COVID- } \\
19 .\end{array}$ & $\begin{array}{l}\text { Maximilian Ackermann, M.D., Stijn E. Verleden, Ph.D., } \\
\text { Mark Kuehnel, Ph.D., et al. The New England Journal of } \\
\text { Medicine, Published on May 21, 2020, at NEJM.org. } \\
\text { DOI: } 10.1056 / \text { NEJMoa2015432 }\end{array}$ & $\begin{array}{c}\text { To compare the morphologic and } \\
\text { molecular features of lungs obtained during } \\
\text { autopsy from patients who died from } \\
\text { COVID-19, with those of lungs from } \\
\text { patients who died from influenza and age- } \\
\text { matched, uninfected control lungs. }\end{array}$ \\
\hline 8 & $\begin{array}{l}\text { Renal histopathological } \\
\text { analysis of } 26 \text { postmortem } \\
\text { findings of patients with } \\
\text { COVID-19 in China. }\end{array}$ & $\begin{array}{c}\text { Hua Su; Ming Yang; Cheng Wan; et al. Kidney International } \\
\text { (2020), } \\
\text { Published online on } 9 \text { April 2020, } \\
\text { https://doi.org/10.1016/j.kint.2020.04.003 }\end{array}$ & $\begin{array}{l}\text { To know the detailed pathology of kidney } \\
\text { damage in patients who died of SARS- } \\
\text { COV-2 infection. }\end{array}$ \\
\hline
\end{tabular}

\section{Number of patients}

Histopathological and macroscopical tissue findings of 109 patients died of COVID-19 were reviewed from the selected research papers.

\section{Specimen collection and pathological examination}

Macroscopical examination and collection of specimens for histopathological examination were done from all the organs in three studies ${ }^{[4,5,8]}$; from lungs, liver and heart in one study ${ }^{[3]}$; from lungs and heart in one study ${ }^{[6]}$; only from lungs in two studies ${ }^{[7,9]}$ and from kidneys in one study ${ }^{(10)}$.

\section{Assay for SARS- CoV-2}

In all the cases real time Reverse Transcriptase Polymerised Chain Reaction (RT-PCR) was performed to confirm SARS-CoV-2 infection. In two studies samples 
from all the tissues were collected for performing RT-PCR during autopsy ${ }^{[3,8]}$ where as in one study nasopharyngeal and lung tissue swabs were collected during autopsy ${ }^{[4]}$. Postmortem nasopharyngeal, tracheal, bronchial swabs and also samples from pleural effusion and cerebrospinal fluid were collected in one study ${ }^{[5]}$. Nasopharyngeal secretion and bronchoalveolar lavage were collected in one study ${ }^{(10)}$. In remaining three studies the cases were diagnosed as positive for SARS-CoV-2 before death ${ }^{[6,7,9]}$.

\section{Age of the patients}

In four studies median age of the patients died of COVID19 were recorded ${ }^{[5,7,8,10]}$ and in the remaining four studies age of individual patients were recorded ${ }^{[3,4,6,9]}$. For easy analysis median age was calculated in all the studies and it is as follows.

Table 2: Median age of the deceased

\begin{tabular}{|c|c|c|}
\hline Name of the study & Number of patients & Median age \\
\hline Study 1 & 4 & 76 years \\
\hline Study 2 & 2 & 59.5 years \\
\hline Study 3 & 10 & 79 years \\
\hline Study 4 & 10 & 64.5 years \\
\hline Study 5 & 38 & 69 years \\
\hline Study 6 & 12 & 73 years \\
\hline Study 7 & 7 & 78 years \\
\hline Study 8 & 26 & 69 years \\
\hline
\end{tabular}

When the median age is calculated in 8 studies which includes 109 cases, most of the cases are above the median age of 64.5 years.

\section{Gender of the patient}

Of the total 109 patients sex ratio is specified only for 99 patients. In one study which includes 10 patients sex ratio was not specified ${ }^{[6]}$.

Table 3: Gender of the deceased

\begin{tabular}{|c|c|c|}
\hline Gender & No. of patients & Percentage \\
\hline Male & 78 & $78.8 \%$ \\
\hline Female & 21 & $21.2 \%$ \\
\hline
\end{tabular}

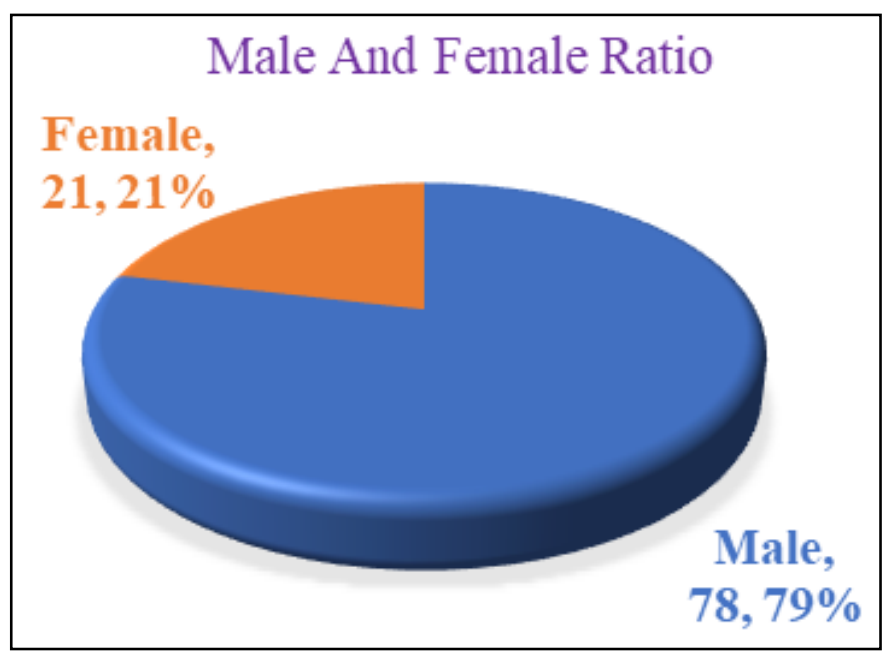

Fig 1: Gender of the deceased

\section{Past History}

Past history of all the patients is not available. Of the available past history, the most frequent past medical history is:

Table 4: Past History of the Deceased

\begin{tabular}{|c|c|c|}
\hline S. No. & Name of the disease & No. of patients \\
\hline 1 & Hypertension & 51 \\
\hline 2 & Diabetes Mellitus & 23 \\
\hline 3 & Obesity & 23 \\
\hline 4 & Coronary Artery Disease & 19 \\
\hline 5 & Carcinoma & 15 \\
\hline 6 & Chronic Obstructive Pulmonary Disease & 12 \\
\hline 7 & Deep Vein Thrombosis & 8 \\
\hline 8 & Ischemic Heart Disease & 6 \\
\hline 9 & Atrial Fibrillation & 5 \\
\hline 10 & Arteriosclerosis & 5 \\
\hline 11 & Chronic Kidney Disease & 5 \\
\hline 12 & Ischemic enteritis & 4 \\
\hline 13 & Hypothyroidism & 2 \\
\hline 14 & Cardiomyopathy & 2 \\
\hline 15 & Cirrhosis of Liver & 1 \\
\hline 16 & Post renal transplantation & 1 \\
\hline 17 & Positive ANA & 1 \\
\hline 18 & Myotonic Dystrophy & 1 \\
\hline 19 & Fatty Liver & 1 \\
\hline 20 & Hyperthyroidism & 1 \\
\hline 21 & Dementia & 1 \\
\hline 22 & Congestive Heart Failure & 1 \\
\hline 23 & Thyroidectomy & 1 \\
\hline 24 & Rheumatoid Arthritis & 1 \\
\hline 25 & Polymyositis & 1 \\
\hline 26 & Immunosuppression & 1 \\
\hline 27 & Obstructive Sleep Apnoea & \\
\hline
\end{tabular}




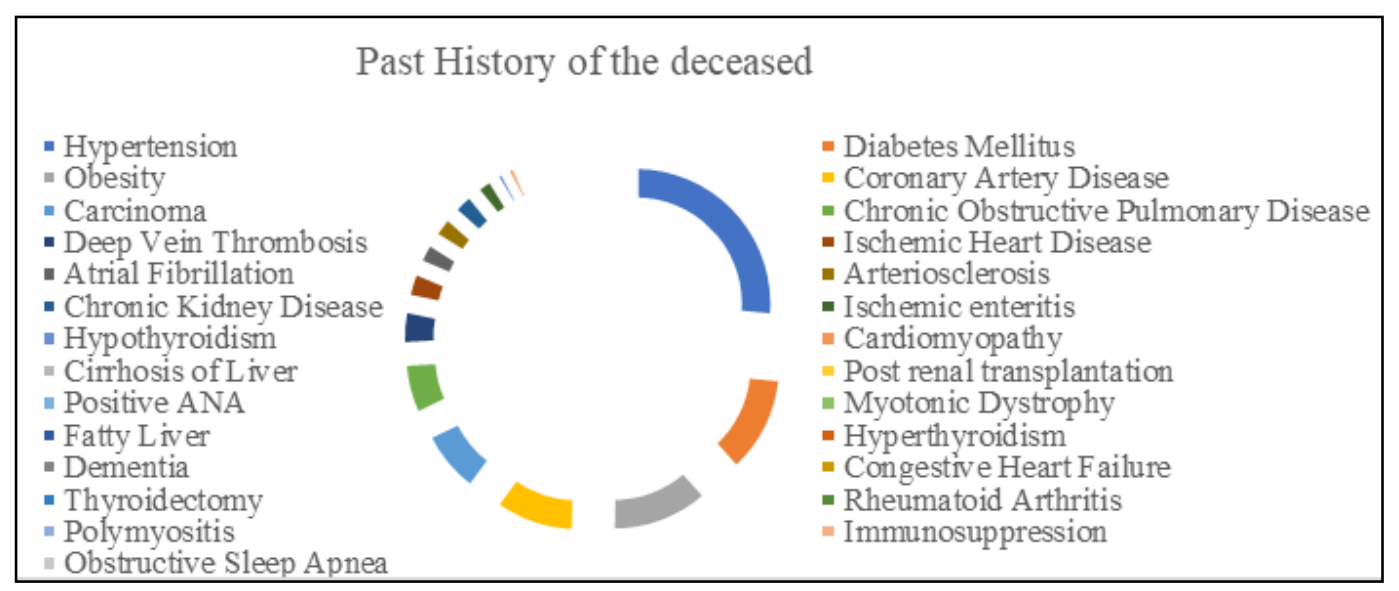

Fig 2: Past History of the Deceased

\section{Findings in Chest Imaging}

Chest imaging findings of all the patients are not available. The main presentation is opacity in lungs, ground glass opacity in lungs, consolidation and combined features of ground glass opacity and consolidation. The exact number is as follows:
Table 5: Chest imaging findings

\begin{tabular}{|c|c|c|}
\hline S.No. & Findings in Chest Imaging & No. of patients \\
\hline 1 & Ground glass opacity in lungs & 59 \\
\hline 2 & Consolidation & 15 \\
\hline 3 & Ground glass opacity and consolidation & 4 \\
\hline 4 & Opacity in Lungs & 2 \\
\hline
\end{tabular}

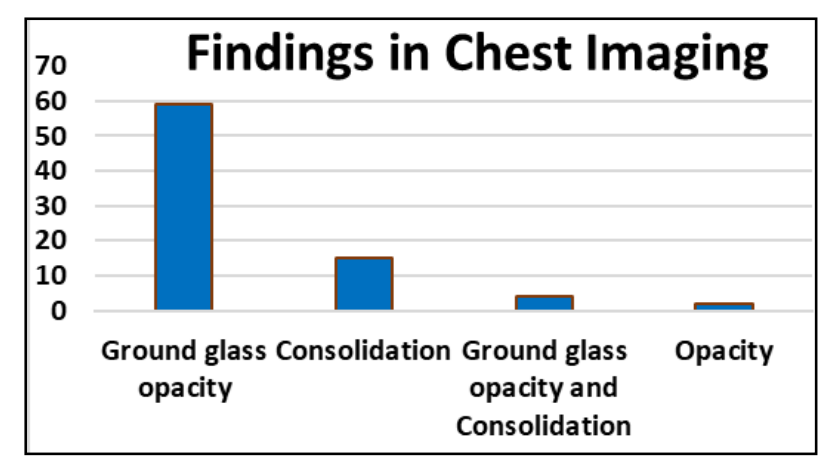

Fig 3: Chest imaging findings

Laboratory Investigation Findings

Lab investigation reports of only limited patients are available. The available data concerned with investigations are:

Table 6: Laboratory Investigation Findings

\begin{tabular}{|c|c|c|}
\hline S. No. & Laboratory Investigations & No. of Patients \\
\hline 1 & Increased D-Dimer & 62 \\
\hline 2 & Lymphocytopenia & 29 \\
\hline 3 & Decreased Hemoglobin count & 26 \\
\hline 4 & Thrombocytopenia & 19 \\
\hline 5 & Leucocytosis & 15 \\
\hline 6 & Increased Lactate Dehydrogenase & 14 \\
\hline 7 & Increased Blood Urea Nitrogen & 11 \\
\hline 8 & Increased Alanine Transaminase & 9 \\
\hline 9 & Increased Aspartate Transaminase & 8 \\
\hline 10 & Increased Neutrophils & 7 \\
\hline 11 & Increased Creatinine Kinase & 7 \\
\hline 12 & Increased creatinine & 7 \\
\hline 13 & Increased C - reactive Protein & 4 \\
\hline 14 & Increased Platelet count & 1 \\
\hline 15 & Increased Fibrinogen & 1 \\
\hline
\end{tabular}




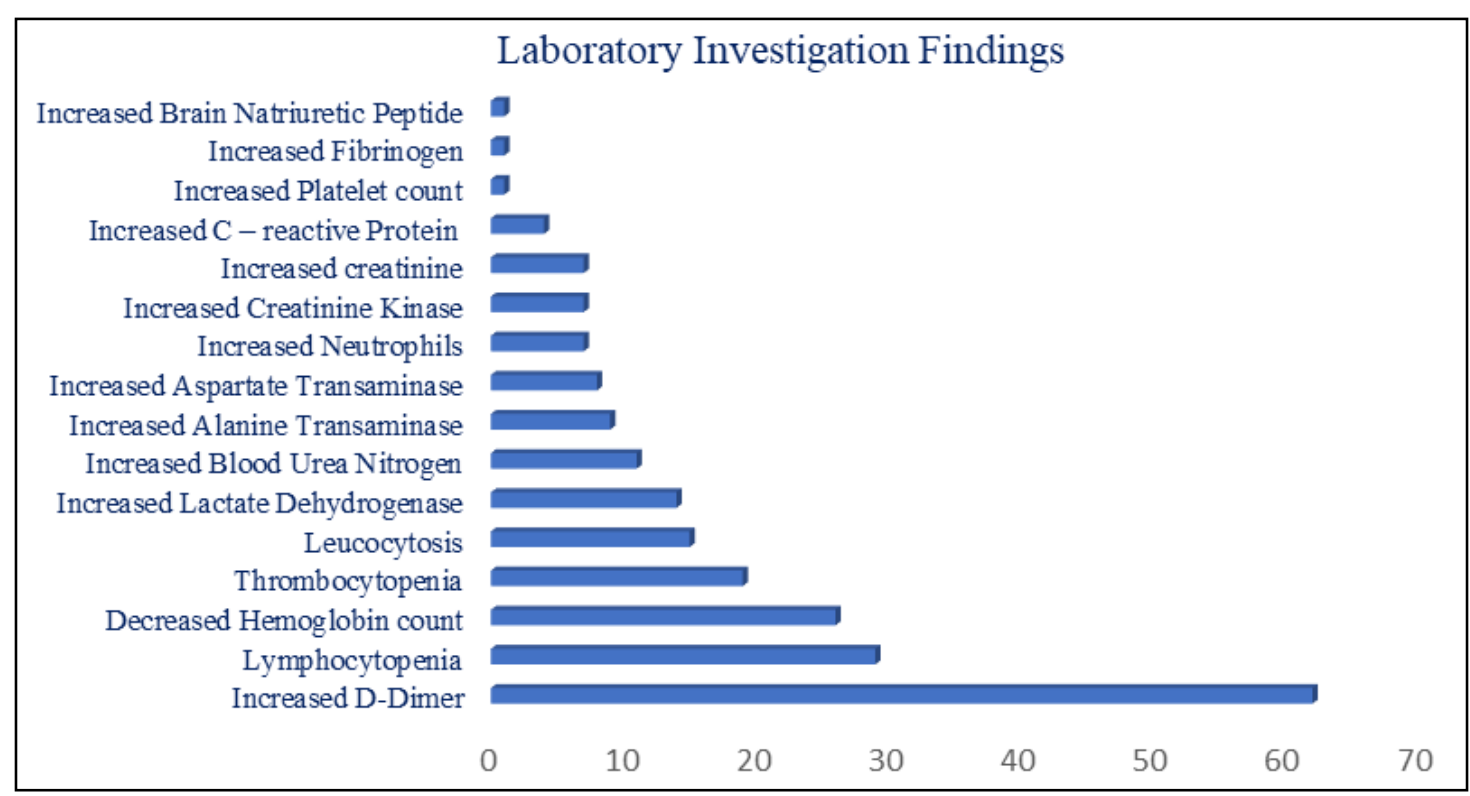

Fig 4: Laboratory Investigation Findings

Macroscopic and Histological appearance of Tissues

Lungs

The histological and macroscopic findings of the lung tissues from 83 patients are available and they are as follows. There are combined histopathological findings in most of the patients.

Table 7: Pathological changes in Lungs

\begin{tabular}{|c|c|c|}
\hline S. No. & Pathological changes & $\begin{array}{c}\text { No. of } \\
\text { patients }\end{array}$ \\
\hline 1 & Diffuse alveolar damage & 68 \\
\hline 2 & Small firm thrombi in sections of peripheral parenchyma & 59 \\
\hline 3 & Heavy lungs & 52 \\
\hline 4 & CD 45 + ive lymphocytes in interstitial space & 38 \\
\hline 5 & CD 68 +ive macrophages in alveolar lumens & 38 \\
\hline 6 & Presence of rare virions in the cytoplasm of pneumocytes. & 38 \\
\hline 7 & Fibrosis & 23 \\
\hline 8 & ARDS & 10 \\
\hline 9 & Persistence of SARS-COV-2 in the respiratoy tract. & 10 \\
\hline 10 & More CD 4 +ive cells & 7 \\
\hline 11 & ACE 2 +ive lymphocytes & 7 \\
\hline 12 & Angiogenesis related genes & 7 \\
\hline 13 & Ultrastructural damage to the endothelium, as well as the presence of intracellular and extracellular SARS-CoV-2. & 7 \\
\hline 14 & Aspiration & 5 \\
\hline 15 & Bronchopneumonia & 5 \\
\hline 16 & Pulmonary thromboembolism & 4 \\
\hline 17 & Focal interstitial thickening & 1 \\
\hline 18 & Thrombi in small pulmonary artery branches & 1 \\
\hline 19 & Acute aspiration bronchopneumonia & 1 \\
\hline 20 & Complete distraction of lung parenchyma & 1 \\
\hline 21 & Pleural adhesion & 1 \\
\hline
\end{tabular}

\section{Liver}

Only few changes in liver were observed and are as follows:

Table 8: Pathological changes in Liver

\begin{tabular}{|c|c|c|}
\hline S. No. & Pathological changes & No. of patients \\
\hline 1 & Changes related to shock & 12 \\
\hline 2 & Signs of fibrosis & 10 \\
\hline 3 & Common non- specific sinusoidal dilatation of terminally ill patient. & 4 \\
\hline 4 & Cirrhosis & 2 \\
\hline 5 & Suggestive of CLL & 1 \\
\hline 6 & Patchy hepatic necrosis in the periportal and centrilobular areas & 1 \\
\hline
\end{tabular}




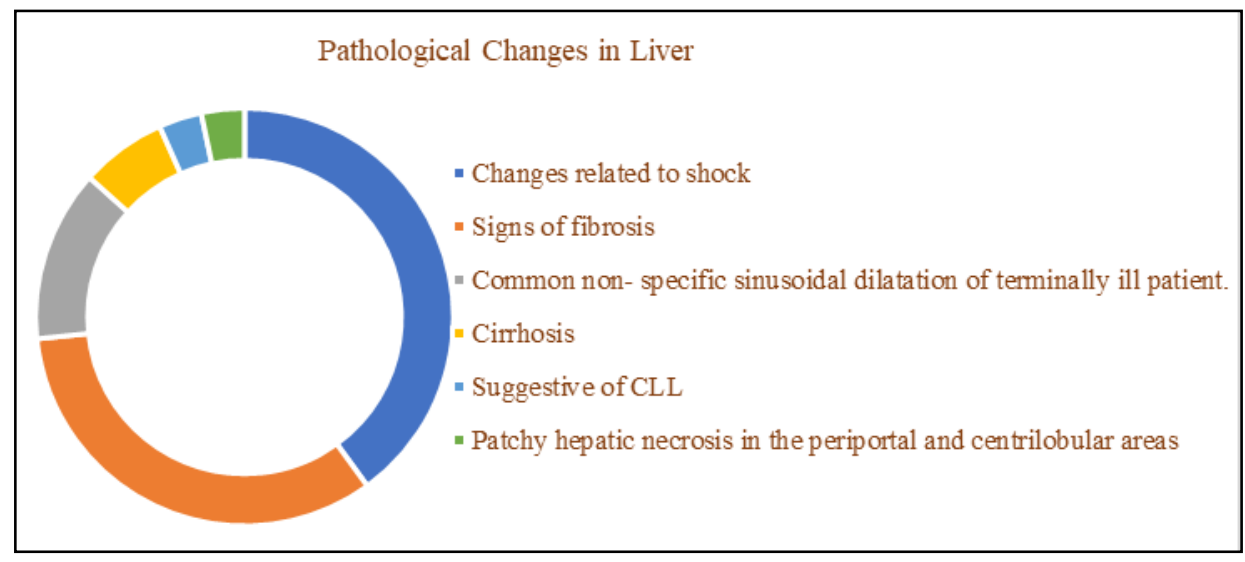

Fig 5: Pathological Changes in Liver

\section{Heart and Circulatory System:}

Following are the changes available in Heart and circulatory system.

Table 9: Pathological changes in Heart and Circulatory system

\begin{tabular}{|c|c|c|}
\hline S. No. & Pathological changes & $\begin{array}{c}\text { No. of } \\
\text { patients }\end{array}$ \\
\hline 1. & Deep Vein Thrombosis in Lower extremities & 12 \\
\hline 2. & Cardiomegaly and right ventricular dilatation & 9 \\
\hline 3. & Scattered individual cell myocyte necrosis & 9 \\
\hline 4. & Lymphocytic myocarditis & 5 \\
\hline 5. & Hypertensive myocardial Hypertrophy & 3 \\
\hline 6. & Ischemic injury & 2 \\
\hline 7. & Coronary artery atherosclerosis & 2 \\
\hline 8. & Epicarditis & 2 \\
\hline
\end{tabular}

\section{Kidney}

The available literature shows the following changes in Kidneys.

Table 10: Pathological changes in Kidney

\begin{tabular}{|r|c|c|}
\hline $\begin{array}{r}\text { S. } \\
\text { No. }\end{array}$ & Pathological changes & $\begin{array}{c}\text { No. of } \\
\text { patients }\end{array}$ \\
\hline 1. & Corona virus like particles in epithelium and podocytes & 26 \\
\hline 2. & Proximal acute tubular injury & 26 \\
\hline 3. & Changes due to shock & 12 \\
\hline 4. & Hypertensive Ischemic glomeruli & 11 \\
\hline 5. & Acute pyelonephritis & 2 \\
\hline 6. & Features of diabetic nephropathy & 2 \\
\hline 7. & Arterionephrosclerosis & 2 \\
\hline 8. & Oncocytoma & 1 \\
\hline
\end{tabular}

\section{Prostate}

The pathological changes of prostate include fresh thrombosis in prostatic venous plexus of six patients and prostatic hyperplasia in one patient.

\section{Other Organs}

The changes in other organs includes the following:

Table 11: Changes in Other Organs

\begin{tabular}{|c|c|c|}
\hline S.No. & Pathological changes & No. of patients \\
\hline 1. & Post splenectomy & 1 \\
\hline 2. & Thyroid nodules & 1 \\
\hline 3. & Chronic pharyngitis & 6 \\
\hline 4. & Changes due to shock in intestine & 12 \\
\hline
\end{tabular}

Presence of Viral particles in RT-PCR Assay and Electron Microscopy

The viral particles were demonstrated by real time Reverse transcriptase- Polymerised Chain Reaction and Electron Microscopy in tissues of the deceased and the details are as follows:

Table 12: Presence of virus particles in various tissues

\begin{tabular}{|c|c|c|}
\hline S. No. & Organs from which viral particles are seen & $\begin{array}{c}\text { No. of } \\
\text { patients }\end{array}$ \\
\hline 1. & Lungs & 72 \\
\hline 2. & Kidney & 31 \\
\hline 3. & Pharynx & 9 \\
\hline 4. & Heart & 8 \\
\hline 5. & Liver & 7 \\
\hline 6. & Brain & 4 \\
\hline 7. & Saphenous vein & 4 \\
\hline 8. & Nasopharyngeal swabs & 2 \\
\hline
\end{tabular}

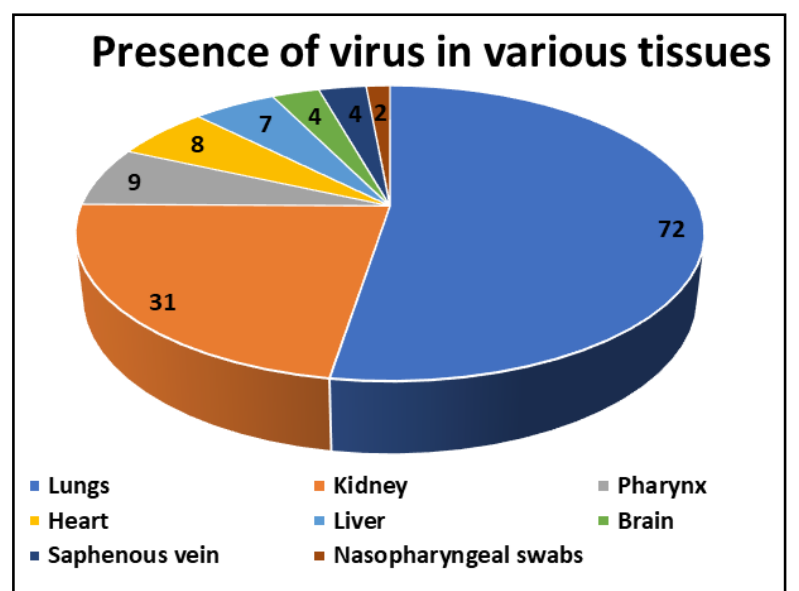

Fig 6: Presence of virus particles in various tissues

\section{Repertorisation}

The pathological changes are mostly found within the lungs. Considering the pathological features following symptoms were considered for repertorisation using RadarOpus 2.2.16.

- Affections of lungs

- Hepatisation of Lungs

- Inflammation of Lungs

- Congestion of Lungs

- Oedema of Lungs

- Thrombosis. 
After Repertorisation, following medicines were indicated.

- Arsenicum album- 6/4

- Aconitum napellus-6/3

- Antimonium tartaricum-6/3
- Arsenicum iodide-5/3

- Belladonna-5/3

- Phosphorus-5/3

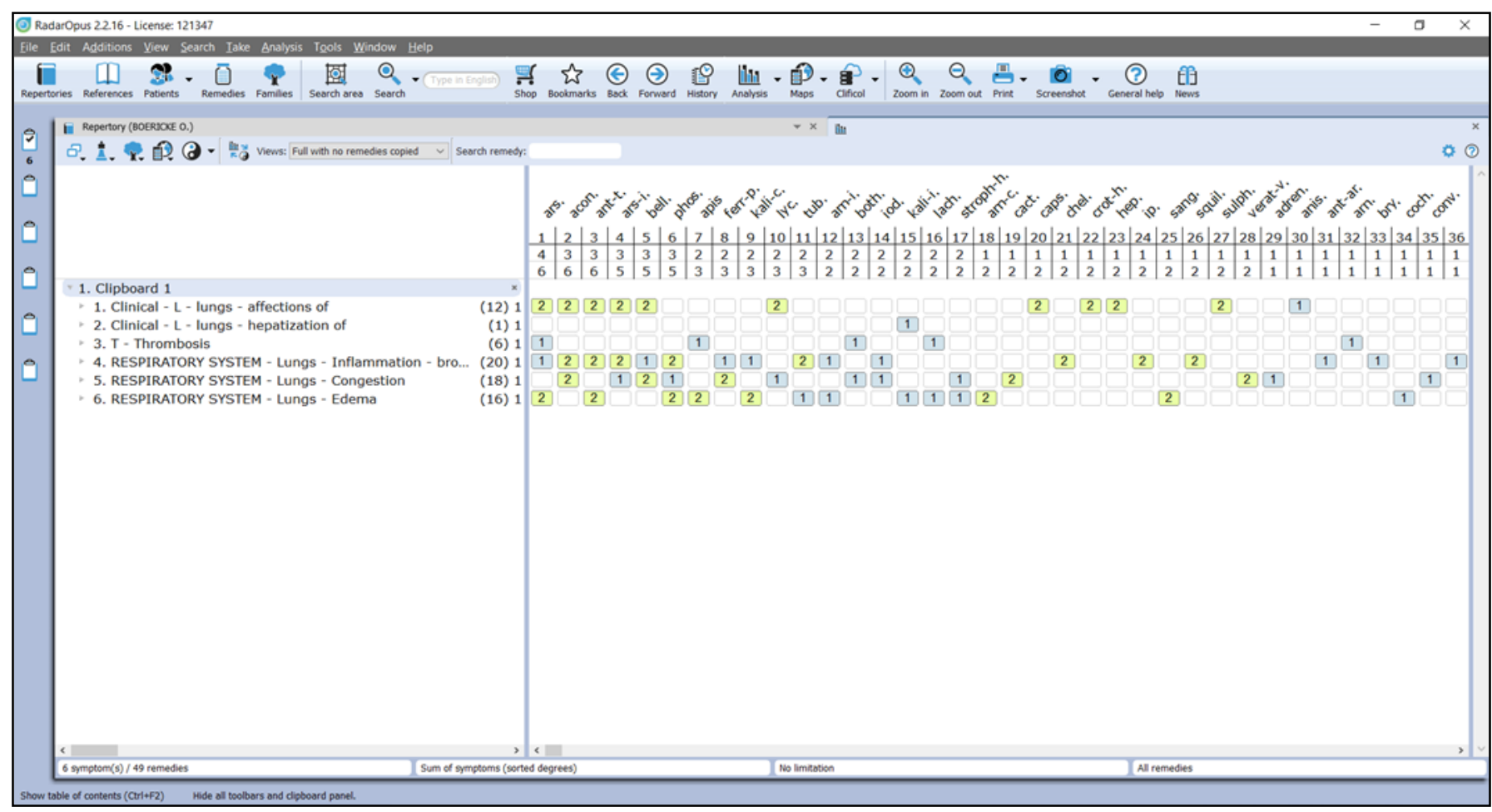

Fig 7: Repertory Chart

\section{Statistical Analysis}

On compilation of data, more pathological changes are found in the Lungs. Pathological changes in lungs of 83 patients were available. Statistical analysis was done on the available data and more prevalence was with diffuse alveolar damage accounting for $81.93 \%$ prevalence followed by small thrombi in sections of peripheral parenchyma of lungs $(71.08 \%)$, heavy lungs $(62.65 \%), \mathrm{CD}$ $68+i v e, C D$ 45+ive and presence of rare virions in pneumocyte cytoplasm accounting for $45.78 \%$, Fibrosis $(27.71 \%)$, ARDS and presence of virus in respiratory tract
(12.05\%), More CD 4 +ive cells, ACE 2 +ive lymphocytes, Angiogenesis related genes and Ultrastructural damage to the endothelium, as well as the presence of intracellular and extracellular SARS-CoV-2 (8.43\%), Aspiration and bronchopneumonia $(6.02 \%)$, Pulmonary thromboembolism (4.82\%), Focal interstitial thickening, Thrombi in small pulmonary artery branches, Acute aspiration bronchopneumonia, Complete distraction of lung parenchyma and Pleural adhesion (1.20\%). Statistical analysis was given in Table 13.

Table 13: Statistical analysis

\begin{tabular}{|c|c|c|c|c|}
\hline $\begin{array}{l}\text { S. } \\
\text { No. }\end{array}$ & Pathological changes in Lungs & $\begin{array}{c}\text { No. of } \\
\text { patients }\end{array}$ & $\begin{array}{c}\text { Prevalence } \\
(\%)\end{array}$ & $\begin{array}{l}95 \% \text { C.I. for } \\
\text { Prevalence }\end{array}$ \\
\hline 1 & Diffuse alveolar damage & 68 & 81.93 & $(73.65,90.21)$ \\
\hline 2 & Small firm thrombi in sections of peripheral parenchyma & 59 & 71.08 & $(61.33,80.84)$ \\
\hline 3 & Heavy lungs & 52 & 62.65 & $(52.24,73.06)$ \\
\hline 4 & CD 45 + ive lymphocytes in interstitial space & 38 & 45.78 & $35.06,56.50)$ \\
\hline 5 & CD 68 +ive macrophages in alveolar lumens & 38 & 45.78 & $(35.06,56.50)$ \\
\hline 6 & Presence of rare virions in the cytoplasm of pneumocytes. & 38 & 45.78 & $(35.06,56.50)$ \\
\hline 7 & Fibrosis & 23 & 27.71 & $(18.08,37.34)$ \\
\hline 8 & ARDS & 10 & 12.05 & $(5.04,19.05)$ \\
\hline 9 & Persistence of SARS-COV-2 in the respiratoy tract. & 10 & 12.05 & $(5.04,19.05)$ \\
\hline 10 & More CD 4 +ive cells & 7 & 8.43 & $(2.46,14.41)$ \\
\hline 11 & ACE 2 +ive lymphocytes & 7 & 8.43 & $(2.46,14.41)$ \\
\hline 12 & Angiogenesis related genes & 7 & 8.43 & $(2.46,14.41)$ \\
\hline 13 & $\begin{array}{l}\text { Ultrastructural damage to the endothelium, as well as the presence of intracellular and } \\
\text { extracellular SARS-CoV-2. }\end{array}$ & 7 & 8.43 & $(2.46,14.41)$ \\
\hline 14 & Aspiration & 5 & 6.02 & $(0.91,11.14)$ \\
\hline 15 & Bronchopneumonia & 5 & 6.02 & $(0.91,11.14)$ \\
\hline 16 & Pulmonary thromboembolism & 4 & 4.82 & $(0.21,9.43)$ \\
\hline 17 & Focal interstitial thickening & 1 & 1.20 & $(0,3.55)$ \\
\hline
\end{tabular}




\begin{tabular}{|l|c|c|c|c|}
\hline 18 & Thrombi in small pulmonary artery branches & 1 & 1.20 & $(0,3.55)$ \\
\hline 19 & Acute aspiration bronchopneumonia & 1 & 1.20 & $(0,3.55)$ \\
\hline 20 & Complete distraction of lung parenchyma & 1 & 1.20 & $(0,3.55)$ \\
\hline 21 & Pleural adhesion & 1 & 1.20 & $(0,3.55)$ \\
\hline
\end{tabular}

\section{Discussion}

The findings from eight research articles that depicts the post-mortem findings of 109 patients died due to COVID-19 were reviewed and summarised. A systemic review and meta-analysis conducted by Jing Yang et al. on prevalence of comorbidities in COVID-19 patients shows that the mean age of patients were 49.6 years ${ }^{[11]}$. A prospective cohort study on predictors of mortality for patients with COVID-19 pneumonia revealed that persons with age 65 or above are prone for death due to pneumonia from SARS-Cov-2 infection ${ }^{[2]}$. The systemic review in cases of death revealed the mean age of the deceased were 64.5 years which substantiates that age equal to or above 65 years is a strong predictor for death due to SARS-Cov-2 infection.

Males are more likely to get infected with SARS-Cov-2 than females and it may be partly due to women's robust innate and adaptive immune responses which make them immune against many bacterial and viral infections ${ }^{[11]}$. In the present study, of the 99 deceased where gender is known 78 $(78.8 \%)$ were males and $21(21.2 \%)$ were females.

Hypertension was the most important comorbidity in patients with COVID-19 followed by diabetes mellitus, cardiovascular disorders and respiratory system disorders [11]. A nationwide analysis of comorbidities conducted in 1590 patients in China revealed that the most important comorbidity was hypertension followed by cardiovascular diseases, cerebrovascular diseases, diabetes mellitus, Hepatitis B infections, Chronic Obstructive Pulmonary Diseases, Chronic Kidney Diseases, malignancy and immunodeficiency ${ }^{[12]}$. Past history of all the 109 patients were not available. Of the available past history (Table 4), hypertension ranks first as of the previous studies in 51 patients; diabetes mellitus and obesity in 23 each; Coronary Artery Disease in 19; malignancy in 15; Chronic Obstructive Pulmonary Disease in 12; Deep Vein Thrombosis in 8; Ischemic Heart Disease in 6; Atrial Fibrillation, Arteriosclerosis and Chronic Kidney Disease in 5; Ischemic enteritis in 4; Hypothyroidism and Cardiomyopathy in 2; Cirrhosis of Liver, Post renal transplantation, Positive ANA, Myotonic Dystrophy, Fatty Liver, Hyperthyroidism, Dementia, Congestive Heart Failure, Thyroidectomy, Rheumatoid Arthritis, Polymyositis, Immunosuppression and Obstructive Sleep Apnoea in 1 patient each.

The available chest imaging results reveals the following. 59 patients presented with Ground glass opacity which is consistent with acute respiratory syndrome and which is also a feature of interstitial pneumonia. 15 patients presented with consolidation for which the most important cause is pneumonia. 4 patients presented with a combined feature of ground glass opacity and consolidation. In 2 patients it is said as bilateral pulmonary opacities and the grade of opacity is not mentioned.

A systematic review and meta-analysis conducted in laboratory findings of COVID-19 revealed that the most prevalent findings increased were C-Reactive Protein followed by decreased albumin, increased Erythrocyte Sedimentation Rate, decreased eosinophils, increased interleukin, lymphopenia and increased Lactate
Dehydrogenase ${ }^{(13)}$.In the present study, investigation reports of only few patients are available and it reveals increased D-Dimer (62); lymphocytopenia (29); decreased haemoglobin count (26); thrombocytopenia (19); leucocytosis (15); increased Lactate Dehydrogenase (14); increased Blood Urea Nitrogen (11); increased Alanine Transaminase (9); increased Aspartate Transaminase (8); increased neutrophils, increased creatinine kinase and increased creatinine (7);increased C - reactive protein (4); increased platelet count, increased fibrinogen and increased Brain Natriuretic Peptide (1).

A case control study on D-dimer as a biomarker for disease severity and mortality in COVID-19 patients showed that there is a significant increase of D-dimer in non-survivors when compared with survivors of COVID-19. The study also suggests that the D-dimer assay may be used a biomarker to assess the clinical outcome of COVID-19 patients ${ }^{[14]}$. The present study also reveals that there is significant increase in D-dimer when compared to other investigations.

Regarding the macroscopic and microscopic appearance of various tissues, more findings were related with the lung tissue. Lungs were heavy than the normal in 52 deceased. The most important finding in the lungs was diffuse alveolar damage (DAD), a common finding in fatal viral infection ${ }^{[4]}$. DAD is a change in early Acute Respiratory Syndrome ${ }^{[8]}$. It is divided in to acute stage, organising stage and end stage DAD depending on the severity of the pathology. In a study, the severity of DAD was recorded and as follows. Acute stage was seen in 5 patients with hyaline membrane formation, intra-alveolar oedema, thickened alveolar septa with perivascular lymphocyte plasmocytic infiltration. Organizing stage was seen in 4 patients with fibroblastic proliferation, partial fibrosis, pneumocyte hyperplasia causing interstitial thickening and collapsed alveoles, patchy lymphocyte infiltration. End-stage DAD was seen in 1 patient who also had a more duration of alveolar damage leading to almost complete distraction of pulmonary parenchyma $^{[5]}$.

Small firm thrombi in sections of peripheral lung parenchyma was seen in 59 patients which may be the association with increased D-dimer in patients with COVID19. CD 45+ive cells in interstitial space and CD 68+ive cells in alveolar lumens were found in 38 patients. SARS-COV-2 particles were identified in the respiratory tract and presence of rare virions in the cytoplasm of pneumocytes were seen in 38 patients and presence of intracellular and extracellular virus was present in the endothelium suggesting the presence of contagious virus in the body even after death. 38 patients showed features of fibrosis while 10 patient presents with developed Acute Respiratory Distress Syndrome. Presence of inflammatory cells were seen which suggest an acute inflammation. Aspiration and Bronchopneumonia due to bacterial infection was seen in 5 patients each which suggest a secondary infection. The rest of the findings as discussed in Table 7 was seen only in few patients.

In liver, heart, prostate and in other organs like spleen, intestine, thyroid and pharynx (Table 8, 9, 11) the findings 
are not significant related to viral infection and their pathological findings are related to the pre-existing medical conditions. In Kidneys (Table 10) there was proximal acute tubular injury with corona virus like particles in epithelium and podocytes suggesting the acute pathology ${ }^{[10]}$.

Corona virus particles are seen in various tissues of the deceased the more number in lungs (72), followed by kidney (31), pharynx (9), heart (8), liver (7), brain and saphenous vein (4), nasopharyngeal swabs (2). This suggests the presence of viral particles in the body that are contagious even after the death.

Pathological changes were more in the lungs. Depending on the pathological findings repertorisation was done with the available rubrics. In repertorisation Arsenicum album comes first followed by Aconitum napellus, Antimonium tartaricum, Arsenicum iodide, Belladonna and Phosphorus.

As more pathological changes were found in the lungs and the SARS CoV-2 is a virus whose primary site of infection is the respiratory tract, a statistical analysis was carried out to find out the prevalence of pathological finding in the lungs. It revealed that the most prevalent pathological change is Diffuse Alveolar Damage which is a pathological change in Acute Respiratory Syndrome and a common finding in fatal viral infection. This is also supported by the presence of virus in the lung parenchyma of 72 deceased. This suggests that pathogens induce a diffuse damage in the alveoli leading to respiratory distress and death.

Only eight research articles covering the post-mortem changes of 109 deceased due to COVID-19 were reviewed and the availability of demographic data, co-morbidities, pathological findings as well as the laboratory investigations of the deceased were limited. As the COVID-19 pandemic is evolving rapidly, further research should be carried out with inclusion of more studies with post-mortem findings for generalisation of results.

\section{Conclusion}

The prevalent pathological finding in the 108 patients reviewed is found to be Diffuse Alveolar Damage in the lungs which is a feature consistent with fatal viral infection leading to Acute Respiratory Distress Syndrome. Arsenicum album is found to be the most suitable remedy depending on the pathological findings of lungs.

\section{Funding}

There is no funding agency.

\section{Acknowledgement}

I thank Smt. Resmy R., Statistical Assistant, National Homoeopathy Research Institute in Mental Health, for doing the statistical analysis of the study.

\section{References}

1. Jean-Louis Vincent, Fabio Taccone S. Understanding pathways to death in patients with COVID-19. www.thelancet.com/respiratory. Vol 8, May 2020. https://doi.org/10.1016/ S2213-2600(20)30165-X.

2. Yang HJ, Zhang YM, Yang M, et al. Re: Predictors of mortality for patients with COVID-19 pneumonia caused by SARSCoV-2: a prospective cohort study. Eur Respir J 2020; in press. https://doi.org/10.1183/13993003.02439-2020.

3. Sufang Tian, Yong Xiong, Huan Liu, et al. Pathological study of the 2019 novel coronavirus disease (COVID-
19) through postmortem core biopsies. Modern Pathology. $\quad 14 \quad$ April 2020. https://doi.org/10.1038/s41379-020-0536-x.

4. Lisa M Barton, Eric J Duval, Edana Troberg, et al. COVID-19 Autopsies, Oklahoma, USA. Am J Clin Pathol 2020;153:725-733.

5. Tina Schaller, MD; Klaus Hirschbühl, MD; Katrin Burkhardt, MD, et al. Post mortem Examination of Patients with COVID-19. American Medical Association, May 21,2020.https://jamanetwork.com.

6. Sharon Fox E, Aibek Akmatbekov, Jack Harbert L et al. Pulmonary and cardiac pathology in African American patients with COVID-19: an autopsy series from New Orleans. Lancet Respir Med 2020, 30243-5.

7. Adi BS. Efficacy of homoeopathic medicines in chronic low back pain: A clinical study. International Journal of Alternative and Complementary Medicine 2020, 17-20. https://doi.org/10.1016/S2213-2600 (20).

8. Luca Carsana, Aurelio Sonzogni, Ahmed Nasr, et al. Pulmonary post-mortem findings in a large series of COVID-19 cases from Northern Italy 2020. https://doi.org/10.1101/2020.04.19.20054262.

9. Dominic Wichmann, Jan-Peter Sperhake, Marc Lütgehetmann, et al. Autopsy Findings and Venous Thromboembolism in Patients with COVID-19.Annals of Internal Medicine. 2020. https://doi.org/10.7326/M20-2003.

10. Maximilian Ackermann, Stijn Verleden E, Mark Kuehnel, et al. Pulmonary Vascular Endothelialitis, Thrombosis, and Angiogenesis in COVID-19. The New England Journal of Medicine 2020, 21. At NEJM.org.

11. Hua Su, Ming Yang, Cheng Wan, et al. Renal histopathological analysis of 26 postmortem findings of patients with COVID-19 in China. Kidney International 2020, 9. https://doi.org/10.1016/j.kint.2020.04.003.

12. Jing Yanga, Ya Zhenga, Xi Goua, et al. Prevalence of comorbidities and its effects in patients infected with SARS-CoV-2: a systematic review and meta-analysis. International Journal of Infectious Diseases 2020, 9195. https://doi.org/10.1016/j.ijid.2020.03.017.

13. Wei-jie Guan, Wen-hua Liang, Yi Zhao, et al. Comorbidity and its impact on 1590 patients with COVID-19 in China: a nationwide analysis. Eur Respir J 2020;55:2000547 https://doi.org/10.1183/ 13993003.00547-2020.

14. Zu-Li Zhang, Yu-Lei Hou, De-Tao Li, et al. Laboratory findings of COVID-19: a systematic review and metaanalysis. Scandinavian Journal of Clinical and Laboratory Investigation. https://doi.org/10.1080/00365513.2020.1768587.

15. Yumeng Yao, Jiatian Cao, Qingqing Wang, et al. Ddimer as a biomarker for disease severity and mortality in COVID-19 patients: a case control study. Journal of Intensive Care 2020;8:49. https://doi.org/10.1186/s40560-020-00466-z. 